Table 1: Multivariable Logistic Regression Examining Associations between RA Baseline Characteristics and History of Transient Joint Episodes Prior to RA diagnosis*

\begin{tabular}{|l|c|c|}
\hline \multirow{2}{*}{ Variable } & \multicolumn{2}{|c|}{$\mathbf{N}=\mathbf{1 3 3}$} \\
\cline { 2 - 3 } & $\mathbf{O R}$ & $\mathbf{9 5 \%}$ CI \\
\hline Age (years) & 0.997 & $0.966,1.029$ \\
\hline Female & 3.303 & $1.165,9.366$ \\
\hline Household annual income $(>\$ 50,000 \mathrm{CAD})$ & 2.539 & $1.063,6.063$ \\
\hline Rheumatic disease comorbidity index & 1.347 & $0.994,1.825$ \\
\hline Osteoarthritis & 3.102 & $0.996,9.658$ \\
\hline Back/spine symptoms & 2.974 & $1.145,7.723$ \\
\hline Seropositivity (RF or ACPA positive) & 3.641 & $1.343,9.873$ \\
\hline CDAI & 0.949 & 0.912 .0 .988 \\
\hline
\end{tabular}

${ }^{*}$ Non-significant variables: current smoker, MD global assessment. 21 patients excluded from multivariable analysis due to missing data

MD medical doctor, RF rheumatoid factor, ACPA anti-citrullinated protein antibodies, CDAI

Clinical Disease Activity Index

Disclosure of Interests: Leah Ellingwood: None declared, Orit Schieir: None declared, Marie-France Valois: None declared, Susan J. Bartlett Consultant for: Pfizer, UCB, Lilly, Novartis, Merck, Jansen, Abbvie, Louis Bessette Grant/research support from: Amgen, BMS, Janssen, Roche, UCB, AbbVie, Pfizer, Merck, Celgene, Sanofi, Lilly, Novartis, Consultant for: Amgen, BMS, Janssen, Roche, UCB, AbbVie, Pfizer, Merck, Celgene, Sanofi, Lilly, Novartis, Speakers bureau: Amgen, BMS, Janssen, Roche, UCB, AbbVie, Pfizer, Merck, Celgene, Sanofi, Lilly, Novartis, Carol Hitchon: None declared, Gilles Boire Grant/research support from: Investigator-initiated studies: Amgen, Abbvie, BMS, Eli Lilly, Merck, Novartis, Pfizer, Consultant for: Advisory boards: Amgen, BMS, Celgene, Eli Lilly, Pfizer, Speakers bureau: Merck, BMS, Pfizer, Glen Hazlewood: None declared, Edward Keystone Grant/research support from: AbbVie, Amgen, Bristol-Myers Squibb, F. Hoffmann-La Roche Inc, Gilead, Janssen Inc, Lilly Pharmaceuticals, Pfizer Pharmaceuticals, Sanofi-Aventis, Consultant for: AbbVie, Amgen, AstraZeneca Pharma, Biotest, Bristol-Myers Squibb Company, Celltrion, Crescendo Bioscience, F. Hoffmann-La Roche Inc, Genentech Inc, Gilead, Janssen Inc, Lilly Pharmaceuticals, Merck, Pfizer Pharmaceuticals, Sandoz, UCB., Speakers bureau: Amgen, AbbVie, Bristol-Myers Squibb Canada, F. Hoffmann-La Roche Inc., Janssen Inc., Merck, Pfizer Pharmaceuticals, Sanofi Genzyme, UCB, Diane Tin: None declared, Carter Thorne Grant/research support from: Investigator-initiated studies: Amgen, Pfizer. RCTs: Abbvie, Celgene, CaREBiodam, Novartis, Pfizer, Consultant for: Advisory board: Abbvie, Amgen, Celgene, Lilly, Medexus/Medac, Merck, Novartis, Pfizer, Sanofi. Consultant: Abbvie, Centocor, Janssen, Lilly, Medexus/Medac, Pfizer, Speakers bureau: Medexus/ Medac, Vivian Bykerk Grant/research support from: Mallinckrodt, BMS, Crescendo Biosciences, Sanofi/Regeneron., Consultant for: Amgen, Pfizer, UCB, Scipher, Sanofi/Genzyme/Regeneron, Janet Pope Consultant for: Eli Lilly and Company

DOI: 10.1136/annrheumdis-2019-eular.2458

\section{FRI0066 ASSESSMENT OF LUNG INVOLVEMENT IN RHEUMATOID ARTHRITIS IN A NORTH AFRICAN COUNTRY}

Olfa Saidane ${ }^{1}$, Leila Gafsi ${ }^{2}$, Hana Sahli ${ }^{1}$, Aicha Ben Tekaya ${ }^{1}$, Rawdha Tekaya ${ }^{1}$, Ines Mahmoud ${ }^{1}$, Leila Abdelmoula ${ }^{1} .{ }^{1}$ Charles Nicole Hospital, Rheumatology Department, Tunis, Tunisia; ${ }^{2}$ Polyclinic El Omrane, Rheumatology Department, Tunis, Tunisia

Background: Rheumatoid arthritis (RA) is a common inflammatory disease developing within joints but extra-articular organs such as the lung could be involved.

Objectives: To determine the frequency and the characteristics of lung involvement in RA Tunisian patients.

Methods: A retrospective study including patients with RA fulfilling ACR/ EULAR 2010 criteria was conducted in a department of rheumatology in the north of Tunisia between 2014 and 2017. Pulmonary involvement was evaluated based on chest clinical symptoms, combined results from chest-X-ray, computed tomography of the chest and pulmonary functional tests. Patients with pulmonary involvement not directly related to RA were excluded from this study (emphysema, neoplasm, infection...)

Results: Sixty five patients with RA were collected. The mean age was 56 years \pm 12.8 years. The mean age of disease onset was $46.4 \pm$ 13.8 years ranging from 17 to 75 years. The mean disease duration was a $9.6 \pm 10.1$ year.A total of 13 patients $(20 \%)$ were noted to have clinical chest symptoms. It was dyspnea ( 9 cases $(13.8 \%)$ ), chest pain (2 cases $(3 \%))$, dry cough $(5$ cases $(7.7 \%)$ ) and expectoration (3 cases $(4.4 \%)$ ). Eight patients $(12.3 \%)$ had crackles in pulmonary auscultation. Mean time to pulmonary involvement onset was 2.5 years [1-4 years]. Chest-X-ray was available in all patients and showed abnormalities in 24 cases (37\%). Chest computed tomography was practiced in 24 patients $(36.9 \%)$ It revealed pulmonary abnormalities in 18 patients $(75 \%$ of those scanned). Chest computed tomography revealed abnormalities in 3 patients $(4.6 \%)$ who hadn't respiratory complaints. Pulmonary functional tests was performed in 26 patients $(40 \%)$ and revealed abnormalities in 3 cases(obstructive signs in 2 cases and association of obstructive and restrictive signs in 1 case)

The overall frequency of lung involvement based on different lung investigations was $27.6 \%$ (18 patients). Parenchyma was the most frequent site of pulmonary involvement: interstitial lung disease was found in 7 cases $(38.8 \%)$; it was a usual interstitial pneumonia in 5 patients $(27.7 \%)$ and nonspecific interstitial pneumonia in 2 cases $(11.1 \%)$. Bronchiectasis was found in 5 cases $(27.7 \%)$, rheumatoid nodule in 4 cases $(22.2 \%$ ) and pleural disease in 2 cases $(11.1 \%)$.

Conclusion: Lung involvement is frequent in RA Tunisian patients and the interstitial lung disease represented the most encountered pulmonary manifestation.

\section{REFERENCES}

[1] Megan S, Bridget FC, Lawrence AH, Ganesh R. Rheumatoid arthritis-associated lung disease. Eur Respir Rev. 2015;24:1-16.

[2] Kawassaki AM, Pereira DAS, Kay FU, Laurindo IMM, Carvalho CRR, Kairalla RA. Pulmonary involvement in rheumatoid arthritis: evaluation by radiography and spirometry. J Bras Pneumol. 2015;41(4):331-42.

Disclosure of Interests: None declared DOI: 10.1136/annrheumdis-2019-eular.7857

\section{FRI0067 ANXIETY AND DEPRESSION IN A PREGNANCY AND RHEUMATIC DISEASES CLINIC}

Cassandra Michele Skinner Taylor, Lorena Pérez Barbosa, María Eugenia Corral Trujillo, Janett Carmen Riegatorres, Dionicio Ángel Galarza-Delgado, Jairo Vladimir Rodriguez Hinojosa. Hospital Universitario Dr José Eleuterio Gonzalez, Monterrey, Mexico

Background: Preconceptional psychologic evaluation allows the identification of risks factors for perinatal disorders. Anxiety (13.4\%) and depression $(41.5 \%)$ has been reported in rheumatic diseases ${ }^{1}$. Hospital Anxiety and Depression Scale (HADS) is used to evaluate anxiety and depression in patients with chronic diseases ${ }^{2}$.

Objectives: To describe the frequency of anxiety and depression disorders among preconceptional patients in a Pregnancy and Rheumatic Diseases Clinic.

Methods: An observational, cross-sectional, and descriptive study was conducted in the Rheumatology Consultation of Hospital Universitario "Dr. José Eleuterio González" in Monterrey, Mexico. We included 100 women aged between 18 and 39 years in the preconceptional stage of the Pregnancy and Rheumatic Diseases Clinic. HADS, which is divided in two subscales, one for anxiety and one for depression, indicating a disorder when a score $\geq 11$ was applied. To evaluate Rheumatoid Arthritis (RA) a Disease Activity Score (DAS28) was used, for Systemic Lupus Erythematous (SLE) a Systemic Lupus Erythematous Disease Activity index (SLEDAI) was performed, and others (Sjögren's syndrome, dermatomyositis and fibromyalgia) were evaluated with the Global Quality of Life (GQL). To analyze differences among groups, Gamma coefficient was used. It was considered a statistically significant $\mathrm{p}<0.05$.

Results: One hundred women in childbearing age were included, with a mean age of 34.48 (SD 18.33) years. RA was diagnosed in $48 \%$, SLE in $37 \%$, and others in $15 \%$. We found a mean HADS total score of 11.73 (7.29), in the anxiety subscale 6.94 (4.027), and depression subscale 4.79 (4.026). A significant correlation between SLE and a high HADS score was observed (Table 1).

Conclusion: In order to have a safe pregnancy, an early intervention to assess the psychiatric status is required in patients with rheumatic diseases.

\section{REFERENCES :}

[1] Quintana, J.M., Padierna, A., Esteban, C., Arostegui, I., Bilbao, A., \& Ruiz, !. (2003). Evaluation of the psuchometric characteristics of the Spanish versión of the Hospital Anxiety and Depression Scale. Acta Scandinavica, 107(3), 216-221.

[2] Zigmond, A. S., \& Snaith, R. P. (1983). The hospital Anxiety and depresión scale. Acta psychiatrica scandinavica, 67(6), 361-370. 
Table 2. Disease activity: DAS28 score, GQL score and anxiety and depression

\begin{tabular}{|c|c|c|c|c|c|c|c|}
\hline & \multicolumn{3}{|c|}{ Anxiety } & \multicolumn{3}{|c|}{ Depression } & \multirow{3}{*}{$\begin{array}{l}\text { HADS total } \\
\text { score }(P)\end{array}$} \\
\hline & Without & With & $\mathbf{P}$ & Without & With & $\mathbf{P}$ & \\
\hline & n (\%) & n (\%) & & n (\%) & n (\%) & & \\
\hline $\begin{array}{l}\text { DAS-28 index } \\
(\mathrm{N}=48)\end{array}$ & $\begin{array}{c}31 \\
(64.4)\end{array}$ & $\begin{array}{c}17 \\
(35.4)\end{array}$ & 0.36 & $\begin{array}{c}34 \\
(70.8)\end{array}$ & $\begin{array}{c}14 \\
(29.2)\end{array}$ & 0.20 & 0.06 \\
\hline $\begin{array}{l}\text { SLEDAI index } \\
(\mathrm{N}=37)\end{array}$ & $\begin{array}{c}22 \\
(59.5)\end{array}$ & $\begin{array}{c}15 \\
(40.5)\end{array}$ & 0.79 & $\begin{array}{c}29 \\
(78.4)\end{array}$ & $\begin{array}{c}2 \\
(21.6)\end{array}$ & 0.42 & 0.05 \\
\hline $\begin{array}{l}\text { GQL index } \\
(\mathrm{N}=15)\end{array}$ & $7(46.7)$ & $\begin{array}{c}8 \\
(53.3)\end{array}$ & 0.50 & $\begin{array}{c}13 \\
(86.7)\end{array}$ & $\begin{array}{c}2 \\
(13.3)\end{array}$ & 0.25 & 0.74 \\
\hline
\end{tabular}

Disease Activity Score 28-joint counts (DAS-28) >5.1 High activity; Systemic Lupus

Erythematosus Disease Activity Index (SLEDAI) $>8$ High activity; Global Quality Index $(G Q L)>8$ high activity. HADS total score $\geq 11$.

Disclosure of Interests: None declared

DOI: 10.1136/annrheumdis-2019-eular.7952

\section{FRI0068 SAFETY OF THE ZOSTER RECOMBINANT ADJUVANTED VACCINE IN RHEUMATOID ARTHRITIS PATIENTS: A SINGLE CENTER'S EXPERIENCE WITH 300 PATIENTS}

Emma Stevens, Michael E. Weinblatt, Elena Massarotti, Frances Griffin, Sonali Desai. Brigham andWomen's Hospital, Division of Rheumatology, Immunology and Allergy, Boston, United States of America

Background: Patients with rheumatoid arthritis (RA) and other systemic rheumatic diseases (SRD) are at increased risk of developing Herpes Zoster $(\mathrm{HZ})$ due to the diseases/or medications used to treat them such as corticosteroids methotrexate, biologic disease modifying agents, and JAK inhibitors. Released in 2018, the Zoster Recombinant Adjuvanted (ZRA) is a new vaccine with $>90 \%$ efficacy and can be used in patients taking immunosuppressive therapy as compared to the live Zoster vaccine $^{1}$. There has been a concern about whether the potency of the adjuvant could trigger flares of the underlying SRD, and whether there will be more side effects in this population.

Objectives: Our goal was to study the impact of the new ZRA vaccine in RA and other SRD patients and to measure the risk of flare and incidence of side effects.

Methods: We performed a retrospective chart review from 2/1/2018 to $1 /$ 20/2019, on patients with RA and SRD seen at the BWH who had received the ZRA vaccine. Co-variates of interest were collected. A flare was defined as occurring within 12 weeks of the vaccine administration by either: 1) documentation of RA flare in the rheumatologist office notes, telephone encounter or patient portal communication, or 2) new prednisone prescription or an increase in dose of existing prednisone prescription. Vaccine side effects were defined as muscle soreness at the injection site, redness, mild swelling, fatigue, fevers, myalgias, headaches, nausea, and abdominal pain.

Results: 300 patients who received the new ZRA vaccine between 2/1/ 2018 to $1 / 20 / 2019$ were identified. Mean follow up was 12.5 weeks ranging from 1-40 weeks following administration. Patient characteristics are identified in Table 1.

We identified a $3.00 \%(n=9)$ incidence of flare following the first dose and $2.86 \%(n=4)$ incidence following the second dose. One patient flared after both the first and second dose. All the flares were mild, self-limited, responded to treatment with low dose glucocorticoids, and did not warrant a change in immunosuppressive therapy. $15.3 \% \quad(n=46)$ patients experienced side effects such as soreness at the injection site, fever, stomach ache, and flu like symptoms. Of the patients who experienced side effects, $15.4 \% \quad(n=40)$ occurred after the first dose and $8.59 \% \quad(n=11)$ occurred following the second dose. Five patients experienced side effects from both. All side effects were regarded as mild and did not necessitate an emergency room visit. No cases of Zoster were reported.

\begin{tabular}{lc}
\hline Total N & 300 \\
\hline Mean Age & $67.5( \pm 11.1)$ \\
Females & $232(77.3 \%)$ \\
Seropositive & $111(53.6 \%)$ \\
Received 2nd Vaccine & $140(46.7 \%)$ \\
Medications & \\
MTX (mean dose=17.1mg/week) & $118(39.3 \%)$ \\
Prednisone (mean dose=4.69 mg/day) & $81(27.0 \%)$ \\
Tofacitinib & $44(14.7 \%)$
\end{tabular}

TNF inhibitors *

$91(30.3 \%)$

Other biologic therapy ** $47(15.7 \%)$

Other immunosuppressants ${ }^{\star * *}$

Diagnosis

RA

Psoriatic Arthritis

$207(69.0 \%)$

$21(7.00 \%)$

Psculitis

$12(4.00 \%)$

SLE

$11(3.67 \%)$

CTD/MCTD

$7(2.33 \%)$

Other ${ }^{* * * *}$

$42(14.0 \%)$

${ }^{*}$ Adalimumab, Certolizumab pegol, Etanercept, Golimumab, Infliximab

** Abatacept, Tocilizumab, Rituximab, Sarilumab

${ }^{* *}$ Azathioprine, Cyclophosphamide, Mycophenolic acid, Leflunomide

${ }^{\star * \star *}$ Other includes: Gout, Scleroderma, Sjogren's, Ankylosing spondylitis, Dermatomyositis

Conclusion: In our experience with 300 patients who received the new ZRA (207 RA and 93 SRD) in 2018-2019, the incidence of disease flares was $\leq 3 \%$ and of side effects was $15 \%$ which is reassuring. Both flares and side effects were mild, self-limited, and did not require a change in DMARD therapy. No cases of Zoster were reported. Larger formal studies with longer term follow up are required to confirm our findings.

\section{REFERENCE:}

[1] Shingrix Recommendations.cdc.gov. https://www.cdc.gov/vaccines/vpd/ shingles/hcp/shingrix/recommendations.html

Disclosure of Interests: Emma Stevens: None declared, Michael E. Weinblatt Shareholder of: Stock option: CanFite, Lycera, Scipher, Inmedix Grant/research support from: Crescendo Bioscience, Bristol Myers Squibb, Sanofi, Consultant for: AbbVie, Amgen, Bristol-Myers Squibb, CanFite Corrona, Crescendo, GlaxoSmithKline, Gilead, Horizon, Lilly, Lycera Merck, Novartis, Pfizer, Roche, Samsung, Scipher, Set Point, Elena Massarotti : None declared, Frances Griffin: None declared, Sonali Desai None declared

DOI: 10.1136/annrheumdis-2019-eular.4337

\section{FRI0069 FREQUENCY OF EYE INVOLVEMENT IN INFLAMMATORY ARTHRITIS AND CONNECTIVE TISSUE DISEASE: A SYSTEMATIC REVIEW AND META- ANALYSIS}

Matthew Turk ${ }^{1}$, Jacqueline Hayworth ${ }^{2}$, Tatiana Nevskaya ${ }^{1}$, Janet Pope ${ }^{1}$. ${ }^{1}$ university of western ontario, London, Canada; ${ }^{2}$ university of toronto, toronto, Canada

Background: Rheumatoid arthritis commonly presents with extraarticular manifestations. Along with other connective tissue diseases, these manifestations may include eye involvement.

Objectives: The purpose of our work was to determine the prevalence and type of eye involvement in rheumatoid arthritis and other connective tissue diseases through a meta-analysis and literature review.

Methods: A systematic review of the literature was performed using Medline, Web of Science, and the Cochrane library from their inceptions until January 7, 2019. Conjunctivitis, keratoconjunctivitis sicca, xeropthalmia, uveitis, eye hemorrhage, optic neuritis, papilledema, orbital disease, retinal artery/vein occlusion, macular edema, retinitis, chorioretinitis, scleritis, iridocyclitits, choroid hemorrhage, blindness and amaurosis fugax were searched for prevalence in patients with rheumatoid arthritis, systemic lupus erythematosus, antiphospholipid syndrome, dermatomyositis, polymyositis, systemic sclerosis, Sjogren's syndrome, undifferentiated connective tissue disease, giant cell arteritis, granulomatosis polyangiitis (GPA; formerly Wegener's granulomatosis, systemic vasculitis, and sarcoidosis.

Results: 3394 studies were identified and 65 included. The prevalence of eye involvement was $18 \%$ in rheumatoid arthritis, $31 \%$ in systemic lupus erythematosus, $35 \%$ in antiphospholipid syndrome, $27 \%$ in giant cell arteritis, $26 \%$ in GPA and $27 \%$ in sarcoidosis. The most common manifestations was dry eyes (keratoconjunctivitis sicca) in most diseases analyzed with a frequency approaching $90 \%$ in Sjogren's syndrome. Anterior and posterior uveitis were the most common OC in sarcoidosis occurring in $16[3-28] \%$ and $6[3-9] \%$ of patients respectively.

Conclusion: Eye involvement is present in approximately one fifth of rheumatoid arthritis patients, and one quarter to one third of patients with other rheumatic diseases. 